\title{
Crimes of Sexual Violence within International Criminal Law: A Historical Outline
}

\author{
Miranda $\operatorname{Das}^{1} \&$ Sukhdev Singh ${ }^{2}$ \\ ${ }^{1}$ Independent Scholar of International Law, Patna, Bihar, India \\ ${ }^{2}$ Department of Humanities \& Social Sciences, National Institute of Technology Patna, Bihar, India \\ Correspondence: Sukhdev Singh, Room No. S-10, CWRS Building, Department of Humanities \& Social Sciences, \\ National Institute of Technology Patna, Ashok Rajpath, Patna- 800005, Bihar, India. Tel: 91-97-0990-3292. E- \\ mail: dr.singhs@outlook.com
}

Received: September 17, 2020

Accepted: November 10, 2020

Online Published: November 25, 2020

doi:10.5539/jpl.v14n1p1

URL: https://doi.org/10.5539/jpl.v14n1p1

\begin{abstract}
This article will provide a synoptic historical outline of international criminal law (ICL) from a gender perspective. An effort is made to highlight the landmark stages in the evolution of the ICL, particularly in its treatment of rape and other sexual crimes perpetrated against women during armed conflict. For this purpose, a critical examination of Nuremberg and Tokyo tribunals, criminal tribunals for Yugoslavia and Rwanda as well as Special Court for Sierra Leone, and the International Criminal Court is attempted. Endeavour is to outline the gender and sexual crimes jurisprudence developed by the above mentioned international criminal tribunals as well as courts, and then to examine its effectiveness in prosecuting crimes of rape and sexual violence carried out against women. An analysis of what might have gone wrong within the ICL in dealing with rape and crimes of sexual nature is also attempted.
\end{abstract}

Keywords: sexual violence, Nuremberg trials, Tokyo trials, International Criminal Tribunal for the Former Yugoslavia, International Criminal Tribunal for Rwanda, international criminal court

\section{Introduction}

In spite of the fact that the United Nations (UN) Charter in its preamble urges us to protect the future generations from the great affliction of war (United Nations [UN], 1945), we are witnessing a multiplication in cases of armed conflicts. These conflicts have catastrophic consequences not only for combatants but also for civilians. In 1999, the UN Security Council took cognizance of the fact and maintained that majority of casualties, who are targeted by armed combatants in any conflict, are civilians (United Nations Security Council Resolution [UNSCR] 1265, 1999). It is pertinent to note at this point that women civilians constitute a great majority as victims of war. In recent years, the connection between sexual violence and armed conflict has attracted international attention and scholarly interest. The UN Security Council in its Resolution 1820 (2008) on Women and Peace and Security recognised the increasing use of sexual violence against women as war tactic to exploit and disgrace members of community or ethnic group, and often such tactics continue to persist even after the armed conflict gets over (UNSCR 1820, 2008).

In this background, this article traverses the history of international criminal law's (ICL) response to crimes of sexual violence committed during an armed conflict. The purpose is to outline the development of gender and sexual crimes jurisprudence within ICL and then to examine its effectiveness in prosecuting crimes of sexual violence. An attempt will also be made to analyse what might have gone wrong in dealing with crimes of sexual violence within the ICL.

\section{Women and Armed Conflict}

The historical indifference to women and their distinct experiences during armed conflict has been noted in feminist scholarship (Copelon, 1995b; Gardam, 1997; Nesiah, 2009). It might be assumed that armed conflict has similar effect on men and women, whether they are combatants or civilians. However, women's experience during armed conflict might be different from men's. The difference depends upon the place women occupy in given societies and is often related to the vulnerabilities of women when armed conflict erupts. The vulnerabilities of women are evident in the regrettable data available on violence against them during armed conflict (United Nations 
Development Fund for Women [UNIFEM], 2010). It is believed that violence against women during armed conflict is an indication of the unequal power relation that exists between women and men, and the suffering experienced by women in such conflicts is a result of their subordinate place (Gardam \& Jarvis, 2001). Women sustain abuse in various forms, for instance, rape, abduction, forced impregnation or induced miscarriages, diseases, slavery, domestic abuse, sex trafficking during and after the armed conflict (Manjoo \& McRaith, 2011). Many of these issues, especially, domestic abuse and trafficking increase in the aftermath of an armed conflict than during the conflict (Manjoo \& McRaith, 2011).

\section{Rape and Sexual Violence within ICL: A Historical Outline}

This section deals with the historical development of ICL from a gender perspective. It may be noted here that this article does not claim to provide a comprehensive history of ICL in its treatment of rape or other crimes of sexual violence. It rather highlights significant points in the evolution of ICL and how it responded to rape and other crimes of sexual violence over the years.

It is noteworthy that limited protections for women in times of armed conflict have existed in most societies. Their common theme has been to prohibit the killing of civilians, especially, children and the elderly, and crimes of sexual nature. However, the ICL has failed to address the specific crimes carried out against girls and women in the event of armed conflict. The events mentioned below might be considered as landmark in the development and codification of the ICL.

\subsection{Sir Peter von Hagenbach's Trial (1474)}

The earliest international war crimes trial documented in history has been Sir Peter von Hagenbach's trial in 1474 in Breisach, Germany, for creating mayhem while serving the Duke of Burgundy. Hagenbach was an alleged perpetrator of rape, murder, and pillage while in charge of governor in the Duke's Alsatian territories from 1460 to 1474 . He was tried for this by a twenty-eight judges' ad hoc tribunal. The judges were from Switzerland, Germany, and Alsace. At the trial, Hagenbach was declared guilty and was imposed a sentence to death, and the sentence was carried out in front of a huge crowd (Cryer, 2005). This trial was seen as a watershed event not only because it formulated a rudimentary version of crime against humanity, and was a first of its kind case to reject the defence of superior orders, but it was also a landmark trial for purportedly charging rape as a war crime (Gordon, 2013). This trial later became precedent for other tribunals to follow, especially, as a forerunner of the proceedings at the Nuremberg trials (Schwarzenberberger, 2008). Several scholars have also cited the Hagenbach trial for asserting that the case represents a precedent for charging rape as war crime (Gordon, 2013; Askin, 1997).

Insofar as sexual atrocities are concerned, Hagenbach was accused of inflicting sexual violence on young girls from all classes, ranks and status, including nuns. It was also widely believed that Hagenbach preferred rape over murder as weapon of terror and atrocity (Gordon, 2013). For instance, the accused reportedly had lust for a young vestal who was part of a cloister of nuns in Breisach. As per the order of Hagenbach, his lieutenants searched for the young vestal in the cloister and having found, took her to Hagenbach, who then raped her. His response to the charge of rape was that he was not guilty of raping the victims. He further maintained that he paid the women in question to have consensual sex with them (Gordon, 2013). It was observed that rape charges were the most persuasive ones, as they were never denied by Hagenbach directly; and there were numerous evidences to establish the crime (Gordon, 2013). However, many scholars have argued that in Hagenbach's trial, rapes were considered illegal, not because it was considered as crime in itself, but because the war itself was seen as undeclared and therefore unjust and non-permissible (Lupig, 2009).

\subsection{Lieber Code (1863) and the First Geneva Convention (1864)}

It was around the nineteenth century that attempts were made to codify ICL or the laws of warfare. For instance, the United States authorized its War Department to enact guidelines to govern the conduct of the Union Army during the Civil War from 1861 to 1865 (Stover, Peskin, \& Koenig, 2016). These guidelines were drafted by Francis Lieber as General Orders No. 100 in 1863. The Lieber Code, which consisted of 159 articles, was derived from international customs and usage (Askin, 1997). It mandated the humane treatment of civilian population in occupied territories, prohibited torture to acquire confessions, and laid out the rights and protections of prisoners of war (Stover et al., 2016). The Lieber Code vehemently prohibited acts of wanton and unwarranted violence. Such acts were considered illegal and were proscribed at every rank in the Union Army. Rape and sexual violence were termed wanton violence and thereby they were not permitted (Article 44, Lieber Code, 1863).

The nineteenth century also witnessed devastations caused by two major wars that compelled several European States to contemplate on a new international humanitarian order. The first was the Crimean War of 1853-1856 in which around 80,000 members of the Franco-British expeditionary force were killed; and the second was the Battle 
of Solferino in northern Italy in 1859 in which Austria, France and Italy lost tens of thousands of soldiers (Stover et al., 2016). Because of the destructions and horrendous conditions caused by these wars, delegates from sixteen European States met in Geneva to discuss the provisions of an international humanitarian agreement in 1863 (https://www.history.com/topics/world-war-ii/geneva-convention). This meeting resulted in the signing of the Convention for the Amelioration of the Condition of the Wounded in the Field in 1864 by twelve European States. This Convention was the first international agreement on the laws of war and hence, referred to as the First Geneva Convention (Stover et al., 2016). The 1864 Convention was considered historic because it aimed at regularizing a situation which until then was arbitrary and chaotic (Askin, 1997). The text of the Convention was relatively short, as it consisted of ten articles, and it conspicuously did not provide any special protection for women, except in case of being wounded. The rationale behind absence of provision of special protection for women was that the number of women's direct participation in war around 1864 was insignificant (Krill, 1985).

\subsection{The Hague Convention IV (1907)}

The International Peace Conference in Copenhagen in 1907 adopted the Lieber Code as international law and formed the core for the Hague Convention IV for respecting the laws and customs of war on land. Article 46 of the Hague Convention IV linked rape with family honour and thereby prohibited it. Article 46 reads, "family honour and rights, individual rights and private property, as well as religious convictions and liberty, must be respected. Private property cannot be confiscated" (Hague Convention IV, 1907). The language of this Article was adopted from the earlier Hague Convention of 1899. It was only by 1945 that rape was considered a violation of Article 46 of the Hague Convention IV. The prohibition of rape placed along with prohibition of depredation and the reference to private property reinforced the idea of rape as a property crime committed against the male members of the family (Crowe, 2016). Although the Lieber Code and the Hague Convention IV made significant advances towards prohibiting the rape of women, yet they were arguably founded on the opinion that women deserved to be protected as they were the property of men.

\subsection{Trials of Nuremberg and Tokyo}

The earliest sustained effort to hold perpetrators of war crimes accountable was made towards the end of the World War II. The trials of thousands of German and Japanese military and civilian officials, who had been accused of wartime crimes, were held in the 1940s and 1950s. These trials were known as trials at the International Military Tribunals at Nuremberg (Nuremberg tribunal) and trials at the International Military Tribunals for the Far East (Tokyo tribunal), and they established many of the core legal principles of ICL of the present time (Stover et al., 2016). However, sexual or gender crimes were not a main concern in the Nuremberg and the Tokyo tribunal (Goldstone Hon, 2002).

There were two separate sets of trials at Nuremberg: the trial of the major war criminals and the lesser war criminals. The Nuremberg Charter, in accordance with which the tribunal tried the major Nazi war criminals, did not list rape amongst the prohibited acts. Nevertheless, the Control Council Law No. 10, which was issued by the occupying powers in Germany to serve as the source for subsequent trials of lesser war criminals, such as armed and national officials at Nuremberg and elsewhere, incorporated rape, for the first time, within the category of "crime against humanity' or 'other inhuman acts' (Das, 2014). Rape was also understandably encompassed as war crime within the category of 'ill treatment' (Lupig, 2009). The French and Soviet prosecutors produced evidences of torturous rape, coerced prostitution, enforced sterilization, sexual maiming, forcible abortion, non-consensual pornography, and sadism at the Nuremberg trials. For instance, prosecutors from Soviet Union attempted to prove that the rape of Soviet women was part of Nazi regime's organised drive of terror and genocide. Likewise, the French prosecutors also attempted to show that rape was used as a form of military retaliation or reprisal. Yet, the tribunal failed to prosecute or convict any of the accused of crimes of sexual violence (Lupig, 2009). In fact, despite evidences being introduced, the judges did not mention rape (Goldstone Hon, 2002). It is often argued that crimes of sexual violence were considered less important by the tribunal because of the prosecutor's inability to publicly document the crimes (Askin, 1997). Indeed, the prosecutors refused to read out the details from the affidavits submitted to them because they felt shocked and embarrassed to speak about such crimes in public (Goldstone Hon, 2002). The blind eye turned by the tribunal to crimes of sexual violence becomes evident when one reads the document on the 'Trials of the Major War Criminals' published by the Secretariat of the tribunal. The document, which was published in two volumes and consisted of more than 800 pages, does not refer to the crime of rape even once.

The Charter of the Tokyo tribunal, which was established through special proclamation by General Douglas MacArthur to try prominent leaders of the Japanese Empire at the end of World War II, similarly, did not contain explicit reference to rape. Nevertheless, the tribunal expressly charged Japanese defendants with rape as war crimes, 
particularly for 20,000 cases of rape committed by Japanese soldiers in the city of Nanking in 1937 (Lupig, 2009). The General Iwane Matsui, Commander Shunroku Hata and Foreign Minister Hirota were tried and found responsible for their involvement in war crimes such as rape in accordance with the theory of vertical liability, which provides that a commander may be considered responsible for war crimes executed by his troops (Ellis, 2007). Therefore, rape was included within the broad indictments of command responsibility for brutalities in Nanking and a paragraph on crimes of sexual violence was devoted in the opinion under the heading 'Rape of Nanking'. The tribunal, however, was criticized for its failure to make victim representation as the victims of rape were not called to provide evidence (Goldstone Hon, 2002).

The Tokyo tribunal was also criticized for ignoring the crime of enforced prostitution of the 'comfort women' in Japanese military brothels. The survivors presented evidence of being coercively taken to rape camps by Japanese soldiers, which was arguably a regular and central part of the Japanese war efforts, at Women's International War Crimes Tribunal in December 2000. Surprisingly, no mention of 'comfort women' and such rape camps was to be found in the peace treaties with Japan (Ellis, 2007).

\subsection{Geneva Conventions (1949) and the Additional Protocols (1977)}

To further strengthen the laws regulating armed conflict, several states came together in 1949 and adopted four new Geneva conventions to codify the war crimes recognised at Nuremberg and Tokyo tribunals. While the first Geneva Convention concerns the wounded and sick on land and emphasizes that members of the armed forces and organised military groups shall be respected and protected in all situations, the second Convention concerns the conditions of the wounded, sick and shipwrecked members of armed forces at sea. Similarly, the third Geneva Convention is concerned with prisoners of war and the fourth with protection of civilians in times of armed conflict. The war crimes committed against the wounded and sick on land and sea, prisoners of war and civilians were regarded as 'grave breaches' of international humanitarian law (IHL). Like genocide and crimes against humanity, such grave breaches invoke the principle of aut dedere aut judicare, that is, extradite or prosecute (Stover et al., 2016)

It is often argued that since 1949 women started enjoying special protection under IHL. There are provisions dealing with women in all the four Geneva Conventions. Nevertheless, the language of the provisions protecting women is different from the language of the provisions protecting combatants and children (Gardam, 1997). For instance, the fourth Geneva Convention in its Article 27 reiterates the need to protect women "against any attack on their honour, in particular against rape, enforced prostitution, or any form of indecent assault" during international armed conflict (Fourth Geneva Convention, 1949). This provision is different from provisions which firmly prohibits violence against combatants. The Article 12 of the first Geneva Convention, for instance, strictly prohibits any form of violence against the sick and wounded members of armed forces on land. Therefore, it is often argued that provisions concerning women in all of the four Geneva Conventions are protective, not prohibitive, in nature, and the reason why they provide protection to women from rape or other sexual crimes is because they implicate women's honour, not because they constitute violence. Furthermore, breach of any of the provisions concerning women in these Conventions is not treated as 'grave breaches' (Gardam, 1997).

On 8 June 1977, Additional Protocol I and Additional Protocol II of the 1949 Geneva Conventions were adopted, which entered into force in 1978, to address changing methods of armed conflicts since World War II. While the Protocol I addresses crimes arising during international armed conflicts, the Protocol II concerns itself with noninternational or internal armed conflicts. These Additional Protocols explicitly prohibit crimes of sexual violence. For instance, Article 75 (2) (b) of Protocol I prohibits "outrages upon personal dignity, in particular humiliating and degrading treatment, enforced prostitution and any form of indecent assault" (Protocol I, 1977). The provision does not specifically mention the crime of rape. On the contrary, the Protocol II prohibits rape. Article 4 (e) of the Protocol II prohibits "outrages upon the personal dignity, in particular, humiliating and degrading treatment, rape, enforced prostitution and any form of indecent assault" (Protocol II, 1977). It is noteworthy that although the Protocols include rape and coerced prostitution, interestingly, they compare these crimes with crimes of honour and esteem rather than with crimes of viciousness. Thus, the Protocols not only obscure the nature of such crime but also reinforce detrimental stereotypes (Das, 2014).

\subsection{International Criminal Tribunals for Former Yugoslavia and Rwanda}

In 1993 and 1994, the UN Security Council took cognisance and thereby established two ad hoc international war crimes tribunals to bring to the book those responsible for the serious violations of humanitarian law carried out in the former Yugoslavia and Rwanda (Askin, 1997). For the former, the International Criminal Tribunal for the former Yugoslavia (ICTY) was set up in accordance with UN Security Council Resolution 827 of 1993 to prosecute those who were responsible for serious violation of IHL in its territory since 1991 (UNSCR 827, 1993). 
For the latter, the International Criminal Tribunal for Rwanda (ICTR) was formed in accordance with the UN Security Council Resolution 955 of 1994 to prosecute those who committed Genocide and other serious violations of IHL in Rwanda, and for those Rwandan citizens who committed similar crimes in neighbouring states between 1 January 1994 and 31 December 1994 (UNSCR 955, 1994).

The Statutes of the ICTY and ICTR suggest that certain forms of offences of sexual violence perpetrated against women in the event of an armed conflict may be considered and punished. It may be noted that sexual violence was not defined under IHL until the judgements of the ICTY and the ICTR (Campbell, 2007). Prosecutor $v$. Akayesu of the ICTR was the first ever case to ascertain the detailed elements of rape in a global context and to prosecute the act of rape within the category of 'crime of genocide' internationally. The Akayesu case defined sexual violence, including rape as:

Any act of a sexual nature which is committed on a person under circumstances which are coercive. Sexual violence is not limited to physical invasion of the human body and may include acts which do not involve penetration or even physical contact. (Prosecutor v. Akayesu, 1996: para. 688)

The Akayesu judgement is often seen as an initial attempt to end international law's incongruity towards rape and other crimes of sexual violence. However, the Akayesu definition had two notable problems. First, it may be difficult for a victim to prove, if required, that he or she had been coerced into sexual activities and thus was a major obstacle to prosecution. Second, the defendant may argue in his or her defence that the victim had consented to the sexual activity. Fortunately, the Trial Chamber, in addressing coercion, did not limit it to only physical force but also included threats, intimidation, extortion, and situations such as armed conflict where coercion may be inherent. It further clarified that in coercive circumstances, the victim's lack of consent need not be proven. (Koenig, Lincoln, \& Groth, 2011). However, the progress in prosecuting the crime of sexual violence, such as rape, stopped with the Akayesu case, and even regressed at times within the ICTR (Powell, 2017). For instance, in Gacumbitsi case of 2006, the prosecutor submitted to the Appeals Chamber that crime of rape needs to be treated in a similar way as 'torture or enslavement' and the prosecution should not be required to prove absence of consent. But the Appeals Chamber affirmed that the lack of consent on the part of the victim and the accused's knowledge of it were requisites that must be proved by the prosecution.

Insofar as ICTY was concerned, rape as a form of torture and sexual enslavement as crime against humanity were the only forms of sexual crimes enumerated in its Statute. However, the tribunal was limited to passing convictions only for rape as a crime against humanity (https://www.icty.org/en/features/crimes-sexual-violence). This gave rise to the problem that there had not been any universal consensus regarding what elements constituted 'crimes against humanity'. An attempt was made to interpret the crime in pursuant to the Secretary General's Yugoslav Tribunal Report of 1993. Paragraph 48 of the report states:

Crimes against humanity refer to inhuman acts of a profoundly serious nature such as wilful killing, torture or rape, committed as part of widespread or systematic attack against any civilian population on national, political, ethnic, racial or religious grounds. In the conflict in the territory of the former Yugoslavia, such as inhumane acts have taken the form of so-called "ethnic cleansing" and widespread and systematic rape and other forms of sexual assault, including enforced prostitution. (Security Council S/ 25704, 1993)

In view of the above-mentioned provision, several victims of rape or other sexual violence crimes could potentially be left out of the jurisdiction of the Tribunal. For example, while systematic rape carried out as per order of the commanding officer could be accepted within the ambit of crimes against humanity, rape committed by a soldier on his own volition could be considered as a case of isolated rape and thereby could be left outside the jurisdiction of the Tribunal (Askin, 1997).

While discussing ICTY, the Kunarac case of 2001 needs to be mentioned. This is because the Trial Chamber in the case encompassed a clear enquiry into the consent of the victim instead of an enquiry into the exercise of force or coercion. The Trial Chamber provided the following definition of rape:

The sexual penetration, however slight: (a) of the vagina or anus of the victim by the penis of the perpetrator or any other object used by the perpetrator; (b) of the mouth of the victim by the penis of the perpetrator; where such penetration occurs without the consent of the victim. Consent for this purpose must be consent given voluntarily, as a result of the victim's free will, assessed in the contents of the surrounding circumstances. The mens rea is the intention to effect this sexual penetration, and the knowledge that it occurs with the consent of the victim. (Prosecutor v. Kunarac, Kovac \& Vukovic, 2001: para. 460)

The Kunarac case, therefore had pointed to the bodily characteristics of penetration along with the absence of consent on the part of victim and the perpetrator's understanding about the non-consensual nature of the sexual 
activity. The second aspect of the Kunarac definition that requires proof that the purported perpetrator committed the sexual act with due knowledge of the victim's lack of consent was seen as a difficult element, especially, during an armed conflict (Koenig et all., 2011).

It is often pointed out that ICTY and ICTR were not initially designed to prosecute sexual crime, such as rape (Haddad, 2010). The reasons why they were not designed so were the procedural problems of monitoring cases at all levels as well as difficulty involved in altering prosecutorial policies of the Office of the Prosecutor (Campbell, 2007). Nevertheless, the tribunals were eventually seen as momentous in their trial of the crimes of sexual violence, particularly rape. It is maintained that Richard Goldstone, the foremost chief prosecutor of the ICTY appointed Patricia Viseur Sellers as Legal Advisor to the Gender-related Crimes to the Office of the Prosecution in order to adopt gender appropriate policies at the ICTY and ICTR. Since Sellers was not based in Rwanda, it was difficult for her to perform an active role in the ICTR. She was, therefore, made a Gender Advisor to the ICTY, but ICTR was left without such an advisor. It was for this reason that ICTY was considered more successful than its counterpart ICTR insofar as outcomes of rape or sexual crimes prosecutions were concerned (Haddad, 2010).

Even though ICTY has been lauded for providing progressive jurisprudence on crimes of sexual violence, yet a closer look at its statistics of cases reveals a significantly low number of prosecutions and convictions. As of September 2016, of the total one hundred and sixty-one accused, seventy-eight were charged for offences of sexual violence. These figures indicate that only forty-eight percent of the defendants had charges of sexual crimes contained in their indictments. Furthermore, out of the seventy-eight accused indicted for crimes of sexual violence, only thirty-two have been sentenced for their involvement in crimes of sexual violence (https://www.icty.org/). This means that of the total number of individuals indicted for crimes of sexual violence, only forty-one percent have been convicted. The percentage appears grimmer if we look at the conviction rate out of the total accused, which is not more than twenty percent.

Talking about the ICTR, of the total ninety-three individuals indicted, fifty-two were charged with sexual crimes, especially, rape. Further, of the fifty-two cases, forty-three cases have advanced to trial, seven cases were referred to national jurisdiction of Rwanda or France for hearing, and two high-profile cases of absconder were to be tried by the Mechanism for International Criminal Tribunals (MICT) (International Criminal Tribunal for Rwanda, 2014). One could get a disappointing picture from the fact that not all cases charging crimes of sexual violence led to convictions at the ICTR. As of 2014, twenty-three accused have been acquitted of sexual crimes, while only thirteen have been sentenced, charges of sexual violence were dropped in six cases by means of plea negotiations or amendment to the indictments, and one accused died during trial (International Criminal Tribunal for Rwanda, 2014).

\subsection{Special Court for Sierra Leone (2002)}

Several hybrid or mixed courts have been established since the ICTY and ICTR to enforce the principles embodied in the Geneva Conventions and other UN Treaties. The Special Court for Sierra Leone (SCSL) was set up by the UN in 2002 to tackle grave crimes that were committed against UN peace keeping forces as well as civilians throughout the civil war from 1991-2002 in Sierra Leone. The SCSL is regarded as the world's first hybrid international criminal tribunal as it resulted out of negotiations between the UN and the Government of Sierra Leone with an authorisation to try those liable for crimes committed in Sierra Leone after 30 November 1996. This Special Court was unique as it was seated in the State where crimes were committed, and it also had effective outreach program on the ground. The SCSL was shut in the year 2013 and Residual Special Court for Sierra Leone (RSCSL) was founded in its place to supervise the on-going legal duties of the SCSL (http://www.rscsl.org/).

Insofar as crimes of sexual violence are concerned, the SCSL cases involved crimes such as rape, sexual slavery, and forced marriage. However, the SCSL judgements in the Prosecutor v. Brima, Kamara and Kanu, also known as Armed Forces Revolutionary Council (AFRC) case, and the Prosecutor v. Fofana and Kondewa, which is popularly known as Civil Defence Force (CDF) trial, adopted a language of exclusion with regard to crimes of sexual violence. In fact, the CDF case did not hear evidence of rape at all (Oosterveld, 2012). It was also pointed out that the Trial Chamber I's majority ruling in the CDF case included beatings, amputations, and imprisonments described by the witnesses as physical or mental violence but excluded rape and sexual violence as physical or mental suffering. What was more problematic was the Chamber's reasoning that "other inhuman acts" could only be interpreted to cover those acts which are of a 'non-sexual nature'. This reasoning was at odds with ICTR jurisprudence developed in the Akayesu case (Kendall \& Staggs, 2005). Likewise, a preponderance of the Trial Chamber in the AFRC case refused to accept Prosecutor's argument of enforced marriage as a category of an inhuman act. On the contrary, the Trial Chamber was of the view that involuntary and coerced marriage would not amount to a 'crime against humanity' as the crime is not of similar gravity as other crimes in the category of 'crime 
against humanity' mentioned in the SCSL Statute. The Appeals Chamber in the case agreed to the Prosecutor's categorisation of forcible marriage as a 'crime against humanity', but refused to enter fresh convictions (Oosterveld, 2012).

\subsection{International Criminal Court (2002)}

It is amid the articulation of sexual violence jurisprudence in the international tribunals that the drafting of the Statute of the International Criminal Court (ICC) took place. The Rome Statute was adopted on 17 July 1998, and the ICC came into force on 1 July 2002. In fact, the ICTY and ICTR were essential foundation for the codification of crimes of sexual violence in the Rome Statute. The ICC is the world's original permanent international criminal court with a mandate to prosecute offenders of war crimes, crimes against humanity, genocide, and aggression (Spees, 2003).

It has been reported that governments and mainstream human rights groups were indifferent to issues of sexual violence during the initial stages of preparing of the Rome Statute. However, the concerted efforts of a group of women from different states, perspectives and disciplines led to the formation of the Women's Caucus for Gender Justice in the ICC, and it began persuading government delegations to incorporate a gender perspective throughout the Rome Statute (Bedont \& Martinez, 1999).

In contrast to the Statutes of the ICTR, ICTY and the SCSL, the Rome Statute was believed to be the "most advanced articulation in the history of gender-based violence in international criminal law" (Inder, 2010). One could witness failures on the part of the ICTY, ICTR and the SCSL to refer to wide ranging crimes of sexual violence other than rape. As noted earlier, even rape was incorporated within the Statute of the ICTY and ICTR only as a 'crime against humanity', omitting it from other classifications of crimes. The Rome Statute, on the other hand, recognises a whole range of crimes of sexual violence, such as sexual enslavement, forced impregnation, compulsory sterilization, involuntary prostitution, and any other sexual crimes of equivalent magnitude.

Even though Rome Statute has detailed and all-inclusive provisions concerning the crimes of sexual violence, it fails to realise its commitment to examine, indict and prosecute these crimes. This becomes evident if one looks at the ICC's cases. For instance, in ICC's first case, the Lubanga case of 2012, no sexual violence charges were confirmed despite great and enormous evidence of such crimes, particularly evidences that girl child soldiers were subjected to sexual slavery in addition to being raped. Likewise, in the Katanga case of 2014, the Chamber found evidences regarding commitment of crimes of rape and sexual slavery beyond reasonable doubt. Nevertheless, the Chamber concluded that the evidences presented to substantiate the accused's responsibility for these crimes did not satisfy beyond reasonable doubt. Therefore, the Trial Chamber acquitted Katanga of rape and sexual slavery as a 'crime against humanity' (ICC, 2018). After Katanga was exonerated of crimes of rape and sexual slavery, and Fatou Bensouda took charge of the Office of the Prosecutor (OTP), a Policy Paper on Sexual and GenderBased Crimes was released in 2014. The Policy paper played an instrumental role in incorporating a gender perspective to the investigations and prosecutions within the ICC. When gender perspective is adopted at the stage of investigation, cases concerning sexual violence crimes are assumed to be more effectively heard as well as evaluated in the $\operatorname{ICC}(\mathrm{Lu}, 2019)$.

The commitment of the 2014 Policy Paper was thought to be achieved in the Bemba case, which was the primary case to convict act of rape as a weapon of war in 2016. However, in 2018, the Appeals Chamber's majority decision cleared Bemba from all the charges of war crimes, including crimes against humanity (ICC, 2019). A positive development within ICC could, however, be seen in the Ntaganda Case. ICC's Trial Chamber held Bosco Ntaganda guilty of eighteen counts of war crimes and crimes against humanity, including rape and sexual slavery in July 2019 (ICC, 2020). As the verdict is currently subject to appeals, it is yet to be seen if the ICC repeats precedents laid down in the Bemba case or upholds its commitment to crimes of sexual violence.

\section{Conclusion}

Sexual exploitation might be the most obvious crime that women suffer during armed conflict. Sexual offences against women in the event of an armed conflict and thereafter were simply accepted as unfortunate side effect and were not recorded in the catalogues of war crimes until the drafting of the ICC Statute. It is maintained that "when war is done, rape is comfortably filed away as a mere and inevitable 'by-product', a matter of poor discipline, the inevitable bad behaviour of soldiers revved up, needy, and briefly 'out of control"' (Copelon, 1995a: 197).

Rape is, however, merely one facet of women's experience. Other distinctive impacts of armed conflict on women are less clearly acknowledged as they are often not the focus unlike the treatment of soldiers.

Furthermore, despite the widespread use of rape and other forms of sexual violence as a weapon of armed conflict, it was not prosecuted for a long time under international law generally and ICL particularly. Sexual violence was 
a concomitant effect of armed conflict and was treated more as crime against women's honour than crime constituting violence against an individual. It appears that the prosecution of rape and other sexual violence were not of urgency within the ICL. The focus of the various tribunals and the courts have been to investigate and prosecute the crimes that were more discernible and conspicuous. This is because ICL has been an extension of the IHL. Therefore, ICL also suffers from the historic lack of gender perspective of IHL.

It was not until 1990s that one could see a gradual change in this perception towards sexual violence. The concerns regarding sexual crimes were brought into the consciousness of ICL by international human rights experts (ASIL, 2013). Attempts were made only in the ICTY and the ICTR to treat sexual violence as a crime under ICL, yet it remains the least condemned war crimes till date (Ginn, 2013). The failure on the part of the ICTY and ICTR is often defended as not having any precedents, which made the task of the tribunals difficult (ASIL, 2013). It appears that by arguing so, the judges and the prosecutors conveniently ignored the precedent set by the Hagenbach case for charging rape as war crime.

It is also important to mention that international tribunals and courts consider rape and other crimes of sexual violence as 'war crimes' only when such crimes have some link with armed conflict. Apparently random and inconspicuous incidents of rape or sexual abuse carried out by soldiers or perpetrators of war are not given due consideration. In doing so, the tribunals and the courts missed out a significant point that perpetrators resorted to crimes of sexual violence against women because of their sex or gender, not because they happen to be at the wrong place in the wrong time of armed conflict.

The gendered character of the ICL also becomes evident when one analyses the issue of 'consent' with respect to crimes of sexual violence. Criminal tribunals, such as ICTY, require proving of victim's lack of consent by the prosecution. This is highly problematic not only because proving victim's lack of consent is a challenging task but also because sexual crimes are the only crimes that require the prosecution to demonstrate victim's lack of consent. The issue of consent does not arise in case of any other war crimes.

The narrow focus of the tribunals and courts as well as the lack of will to investigate led to the marginalisation of crimes of sexual violence and rape within the scope of ICL. This marginalisation also resulted from the fact that the participants in the various tribunals and courts as defendants, prosecutors and judges were primarily men. This has resulted in a lack of gender perspective within ICL. One could see that participation of women could bring a different outlook to the table. For instance, in the Akayesu case of the ICTR, there was just one woman judge, named Navi Pillay, whose contribution made the case a landmark in the history of prosecuting sexual crimes within ICL. The judgement that rape and sexual violence could constitute 'genocide' is attributed to her, and it is considered extremely innovative in the history of ICL. Reference may also be made to judge Florence Mumba for her immense contribution to the Kunarac case of the ICTY.

Therefore, it can be concluded that where there was will to prosecute rape and other sexual crimes, the way to do so was devised. The failure on the part of ICL to successfully prosecute crimes of sexual violence might be attributed to the lack of will on the part of judges and prosecutors. Or one might argue the other way round that there was will to exclude crimes of sexual violence from the scope and application of ICL.

\section{References}

ASIL 1906. (2013). The prosecution of gender-based crimes by International Criminal Courts: An assessment of successes. YouTube, 12 June. Retrieved from https://www.youtube.com/watch?list=UUwwYEEFmyaqC12bdmWsDs8w\&time_continue $=729 \& \mathrm{v}=0 \mathrm{ENN}$ C05wGOQ\&feature $=$ emb_logo

Askin, K. D. (1997). War crimes against women: Prosecution in war crimes tribunals. The Netherlands: Martinus Nijhoff Publishers.

Bedont, B., \& Martinez, K. H. (1999). Ending impunity for gender crimes under the International Criminal Court. The Brown Journal of World Affairs, 6(1), 65-85. Retrieved from https://www.jstor.org/stable/pdf/24590222.pdf?refreqid=excelsior\%3A44a55a94212277d411c96ae8b8f4b83 4

Campbell, K. (2007). The gender of transnational justice: Law, sexual violence and the International Criminal Tribunal for the Former Yugoslavia. The International Journal of Transnational Justice, 1(3), 411-432. https://doi.org/10.1093/ijtj/ijm033

Convention Respecting the Laws and Customs of War on Land. (1907). Retrieved from https://www.loc.gov/law/help/us-treaties/bevans/m-ust000001-0631.pdf 
Copelon, R. (1995a). Gendered war crimes: Reconcenptualizing rape in time of war. In J. Peter, \& A. Walper (Eds.), Women's rights human rights: International feminist perspective (pp. 197-214). New York NY: Routledge.

Copelon, R. (1995b) Women and war crimes. St. John's Law Review, 69(1), 61-68. Retrieved from https://scholarship.law.stjohns.edu/cgi/viewcontent.cgi?article=1633\&context=lawreview

Crowe, A. (2016). All regard due to their sex: Women in the Geneva Conventions of 1949. Human right program research working paper series. Retrieved from https:/hrp.law.harvard.edu/wpcontent/uploads/2016/12/Anna-Crowe_HRP-16_001.pdf

Cryer, S. (2005). Prosecuting international crimes: Selectivity and the international criminal law regime. Cambridge: Cambridge University Press. https://doi.org/10.1017/CBO9780511494161

Das, M. (2014). Law relating to rape: An international humanitarian perspective. Journal of Law and Public Policy, $1(1), 59-73$.

Ellis, M. (2007). Breaking the silence: Rape as an international crime. Case Western Reserve Journal of International Law, 38(2), 225-247. $\quad$ Retrieved from https://scholarlycommons.law.case.edu/cgi/viewcontent.cgi?article $=1335 \&$ context $=$ jil

Gardam, J. (1997). Women and the law of armed conflict: Why the silence? The International and Comparative Law Quarterly, 46(1), 55-80. https://doi.org/10.1017/S0020589300060115

Gardam, J. G., \& Jarvis, M. J. (2001). Women, armed conflict and international law. The Hague: Kluwer Law International.

Ginn, C. (2013). Ensuring the effective prosecution of sexually violent crimes in the Bosnian war crimes chambers: Applying lessons from the ICTY. Emory International Law Review, 27(1), 565-601. Retrieved from https://law.emory.edu/eilr/_documents/volumes/27/1/comments/ginn.pdf

Goldstone Hon, R. J. (2002). Prosecuting rape as a war crime. Case Western Reserve Journal of International Law, 34(3), 277-285. Retrieved from https://scholarlycommons.law.case.edu/cgi/viewcontent.cgi?article=1461\&context=jil

Gordon, G. S. (2013). The trial of Peter von Hagenbach: Reconciling history, historiography and International Criminal Law. In K. J. Heller, \& G. Simpson (Eds.), The hidden histories of war crimes trials (pp. 13-49). United Kingdom: Oxford University Press. https://doi.org/10.1093/acprof:oso/9780199671144.003.0002

Haddad, H. N. (2011). Mobilizing the will to prosecute: Crimes of rape at the Yugoslav and Rwandan Tribunals. Human Rights Review, 12(1), 109-132. https://doi.org/10.1007/s12142-010-0163-x

History.com Editors. (2018). Geneva Convention. Retrieved from https://www.history.com/topics/world-warii/geneva-convention

Inder, B. (2010). Making a statement: A review of charges and prosecutions for gender based crimes before the International Criminal Court. Women's Initiatives for Gender Justice. Retrieved from http://www.iccwomen.org/publications/articles/docs/MaS22-10web.pdf

International Criminal Court. (2014). Case information sheet: The Prosecutor v. Thomas Lubanga Dyilo, ICC01/04-01/06. Retrieved from https://www.icc-cpi.int/CaseInformationSheets/LubangaEng.pdf

International Criminal Court. (2018). Case information sheet: The Prosecutor v. Germain Katanga, ICC-01/0401/07. Retrieved from https://www.icc-cpi.int/CaseInformationSheets/katangaEng.pdf

International Criminal Court. (2019). Case information sheet: The Prosecutor v. Jean-Pierre Bembe Gombo, ICC01/05-01/08. Retrieved from https://www.icc-cpi.int/CaseInformationSheets/bembaEng.pdf

International Criminal Court. (2020). Case information sheet: The Prosecutor v. Bosco Ntaganda, ICC-01/0402/06. Retrieved from https://www.icc-cpi.int/CaseInformationSheets/NtagandaEng.pdf

International Criminal Tribunal for Rwanda. (2014). Prosecution of sexual violence, best practices manual for the investigation and prosecution of sexual violence crimes in post-conflict regions: Lessons learned from the Office of the Prosecutor for the International Criminal Tribunal for Rwanda. Retrieved from https://unictr.irmct.org/sites/unictr.org/files/publications/ICTR-Prosecution-of-Sexual-Violence.pdf

Kendall, S., \& Staggs, M. (2005). Silencing sexual Violence: Recent developments in the CDF case at the Special Court for Sierra Leone. U. C. Berkeley War Crimes Studies Center. Retrieved from https:/humanrights.stanford.edu/sites/g/files/sbiybj5951/f/publications/silencing_sexual_violence_recent_development_in_the_cdf_case_at_the_special_court_for_sierra_leone.pdf 
Koenig, K. A., Lincoln, R., \& Groth, L. (2011). The jurisprudence of sexual violence. A working paper of the sexual violence and accountability project. Berkeley: Human Rights Center University of California. Retrieved from https://humanrights.berkeley.edu/sites/default/files/publications/the-jurisprudence-of-sexualviolence-sv-working-paper_0.pdf

Krill, F. (1985). The protection of women in international humanitarian law. International Review of the Red Cross, 25(249), 337-363. https://doi.org/10.1017/S002086040002489X

Lu, Y. N. N. (2019). Gender-based war crimes: Its gradual evolution and future. The Yale Review of International Studies. Retrieved from http://yris.yira.org/essays/3538

Lupig, D. (2009). Investigation and prosecution of sexual and gender-based crimes before the International Criminal Court. American University Journal of Gender, Social Policy and the Law, 17(2), 431-496. Retrieved from https://digitalcommons.wcl.american.edu/cgi/viewcontent.cgi?article=1030\&context $=$ jgspl

Manjoo, R., \& McRaith, C. (2011). Gender-based violence and justice in conflict and post-conflict areas. Cornell International Law Journal, 44(1), 11-31. Retrieved from https://www.lawschool.cornell.edu/research/ILJ/upload/Manjoo-McRaith-final.pdf

Nesiah, V. (2009). The specter of violence that haunts the UDHR: Turn to ethics and expertise. Maryland Journal of International Law, 24(1), 135-154. Retrieved from https://digitalcommons.law.umaryland.edu/cgi/viewcontent.cgi?article=1501\&context=mjil

Oosterveld, V. (2012). Gender and the Charles Taylor case at the Special Court for Sierra Leone. William \& Mary Journal of Women and the Law, 19(1), 7-33. Retrieved from https://www.womenslinkworldwide.org/en/files/1221/gender-and-the-charles-taylor-case-at-the-specialcourt-for-sierra-leone.pdf

Powell, C. (2017). 'You have no God': An analysis of the prosecution of genocidal rape in international criminal law. Richmond Public Interest Law Review, 20(1), 25-48. Retrieved from https://scholarship.richmond.edu/cgi/viewcontent.cgi?article=1387\& context=pilr

Prosecutor v. Akayesu. (1998). Case No. ICTR-96-4-T. Retrieved from https://unictr.irmct.org/sites/unictr.org/files/case-documents/ictr-96-4/trial-judgements/en/980902.pdf

Prosecutor v. Brima, Kamara, \& Kanu. (2007). Case No. SCSL-04-16-T. Retrieved from http://www.rscsl.org/Documents/Decisions/AFRC/613/SCSL-04-16-T-613s.pdf

Prosecutor v. Dragoljub Kunarac, Radomir Kovac, \& Zoran Vukovic. (2001). Case No. IT-96-23-T \& IT-96-23/1T. Retrieved from https://www.icty.org/x/cases/kunarac/tjug/en/kun-tj010222e.pdf

Prosecutor v. Fofana. \& Kondewa. (2007). Case No. SCSL-04-14-T. Retrieved from http://www.rscsl.org/Documents/Decisions/CDF/796/SCSL-04-14-T-796.pdf

Residual Special Court for Sierra Leone. Special Court for Sierra Leone. Retrieved from http://www.rscsl.org/

Schwarzenberger, G. (2008). The judgement of Nuremberg. In G. Mettraux (Ed.), Perspectives on the Nuremberg Trial (pp. 167-189). Oxford: Oxford University Press.

Security Council. (1993). Report of the Secretary-General pursuant to paragraph 2 of the Security Council $\begin{array}{llllll}\text { Resolution } & 808 & \text { (1993) } & \text { S/ } & 25704 . & \text { Retrieved }\end{array}$ https://www.securitycouncilreport.org/atf/cf/\%7B65BFCF9B-6D27-4E9C-8CD3CF6E4FF96FF9\%7D/ICTY\%20S\%2025704\%20statute_re808_1993_en.pdf

Spees, P. (2003). Women's advocacy in the creation of the International Criminal Court: Changing the landscapes of justice and power. Signs, 28(4), 1233-1254. https://doi.org/10.1086/375498

Stover, E., Peskin, V., \& Koenig, A. (2016). Hiding in plain sight: The pursuit of war criminals from Nuremberg to the war on terror. California: University of California Press. https://doi.org/10.1525/9780520962767

The International Military Tribunal. (1947). Trials of the major war criminals before the International Military Tribunal. Vol. I. Nuremberg: Germany. Retrieved from https://www.loc.gov/rr/frd/Military_Law/pdf/NT_Vol-I.pdf

The International Military Tribunal. (1947). Trials of the major war criminals before the International Military Tribunal. Vol. II. Nuremberg: Germany. Retrieved from https://www.loc.gov/rr/frd/Military_Law/pdf/NT_Vol-II.pdf

The Leiber Code. (1863). Instructions for the government of armies of the United States in the field. Retrieved 
from http://www.ecclesia.org/forum/library/Lieber_Code.pdf

UNIFEM. (2010). Fast facts: Statistics on violence against women and girls. Retrieved from www.endvawnow.org/en/articles/299-fast-facts-statistics-on-violence-against-women-and-girls-.html

United Nations International Criminal Tribunal for the former Yugoslavia. Retrieved from https://www.icty.org/en/features/crimes-sexual-violence/in-numbers

United Nations. (1945). Charter of the United Nations and Statute of the International Court of Justice. New York: United Nations.

United Nations. (1950). Geneva Convention for the Amelioration of the Condition of the Wounded and Sick in Armed Forces in the Field (1949). UNTS, 75, 31-83. Retrieved from https://reaties.un.org/doc/Publication/UNTS/Volume\%2075/v75.pdf

United Nations. (1950). Geneva Convention for the Amelioration of the Condition of the Wounded, Sick and Shipwrecked Members of Armed Forces at Sea (1949). UNTS, 75, 85-133. Retrieved from https://treaties.un.org/doc/Publication/UNTS/Volume\%2075/v75.pdf

United Nations. (1950). Geneva Convention Relative to the Treatment of Prisoners of War (1949). UNTS, 75, 135417. Retrieved from https://treaties.un.org/doc/Publication/UNTS/Volume\%2075/v75.pdf

United Nations. (1979). Protocol Additional to the Geneva Conventions of 12 August 1949 and Relating to the Protection of Victims of International Armed Conflicts (Protocol I) (1977). UNTS, 1125, 3-545. Retrieved from https://treaties.un.org/doc/Publication/UNTS/Volume\%201125/volume-1125-I-17512-English.pdf

United Nations. (1979). Protocol Additional to the Geneva Conventions of 12 August 1949 and Relating to the Protection of Victims of Non-international Armed Conflicts (Protocol II) (1977). UNTS, 1125, 609-699. Retrieved from https://treaties.un.org/doc/Publication/UNTS/Volume\%201125/volume-1125-I-17513English.pdf

United Nations. (1993). Security Council Resolution 827. Retrieved from http://www.ohr.int/other-doc/un-resbih/pdf/827e.pdf

United Nations. (1994). Security Council Resolution 955. Retrieved from http://unscr.com/en/resolutions/doc/955

United Nations. (1999). Security Council Resolution 1265 on the Protection of Civilians in Armed Conflict. Retrieved from http://unscr.com/files/1999/01265.pdf

United Nations. (2008). Security Council Resolution 1820 on Women and peace and security. Retrieved from https://www.un.org/ruleoflaw/files/women_peace_security_resolution1820.pdf

\section{Copyrights}

Copyright for this article is retained by the author(s), with first publication rights granted to the journal.

This is an open-access article distributed under the terms and conditions of the Creative Commons Attribution license (http://creativecommons.org/licenses/by/4.0/). 